\title{
MILK PRODUCTION FROM RYEGRASS VARIETIES
}

\author{
G. F. WILSON \\ Massey University, Palmerston North
}

J NTRODUCTION

IN VIEW of the importance of the different ryegrass varieties to grassland farming in $\mathrm{N}$ ew Zealand, and the almost complete dearth of information relating to their nutritive value as feeds for dairy cattle, a comprehensive series of experiments was initiated at Massey University.

Nutritive value is a very general term, in that it may refer to a single characteristic, or collectively to a number of different characteristics of a feedstuff, including the presence of energy-producing and protein-forming constituents, together with essential minerals and vitamins necessary for animal health. In addition, a feedstuff should be free of potentially toxic substances or compounds that may be detrimental to the final dairy product. Energy intake, however, is the most common deficiency with grazed herbage in New Zealand, so that dairy production generally depends on the amount eaten and the net energy value of each unit of feed. Both factors need to be measured in any assessment of a feedstuff.

Although accurate methods are available for measuring intake and net energy values under indoor conditions, existing methods applicable to the grazing cow are not sufficiently accurate for general application. For this reason animal output may be used as an indirect assessment of net energy intake. It may be argued that, since animal production is what matters in the long run, the grazing animal must be the final arbiter in deciding the value of a pasture.

\section{EXPERIMENTAL DETAILS}

In the majority of the experiments undertaken, the same basic design was employed. All cows used in an experiment were grazed together for a preliminary period on typical dairy farm mixed pasture. Following this period, identical twin pair mates were separated and allocated to the rye- 
grass treatments. Experiments were invariably short term, lasting from two to ten weeks according to area of pasture and numbers of twin pairs available. Different pastures were grown in several paddocks, each about an acre, and in most cases pure swards were used necessitating regular application of artificial nitrogen. The objective of management was to ensure that, throughout each experiment, cows in the different groups were fed pasture at a similar stage of growth and in sufficient quantity to ensure full feeding. This was achieved by providing cows with a fresh break of grass twice daily by use of an electric fence.

The use of pure swards had several advantages. Differences in animal performance resulting from the ryegrasses were not masked by the presence of other species. The very difficult task of maintaining different species as a constant proportion of a mixed sward was avoided and representative sampling was facilitated. This technique, however, reduces the applicability of results to the more common situation where several different species are grown together, so that it is probably important to complement these experiments with others using mixed swards.

\section{PERMANENT PASTURE VARIETIES}

\section{SPRING EXPERIMENTS}

The first comparison was between 'Grasslands Ruanui' and 'Grasslands Manawa' ryegrasses and the recently introduced 'Grasslands Ariki' ryegrass. This experiment, as were several others, was undertaken in co-operation with the Grasslands and Plant Chemistry Divisions of D.S.I.R. because of their interest in the performance of the grasses, and the New Zealand Dairy Research Institute which is concerned with the quality of milk and milk products.

In the spring of two consecutive years, the three ryegrasses were compared using twelve pairs of twins in a balanced incomplete block design. Grazing commenced towards the end of September and concluded late in November. The results were similar in both years and have been combined in Fig. 1.

The highest milk yield was obtained from the group of animals grazing Manawa ryegrass. The yield from this group was significantly higher than that from the group grazing Ariki ryegrass, and this in turn was significantly higher than that from the cows on Ruanui ryegrass. The differences between these groups of cows reached a maximum towards the end of the experimental period, the difference 

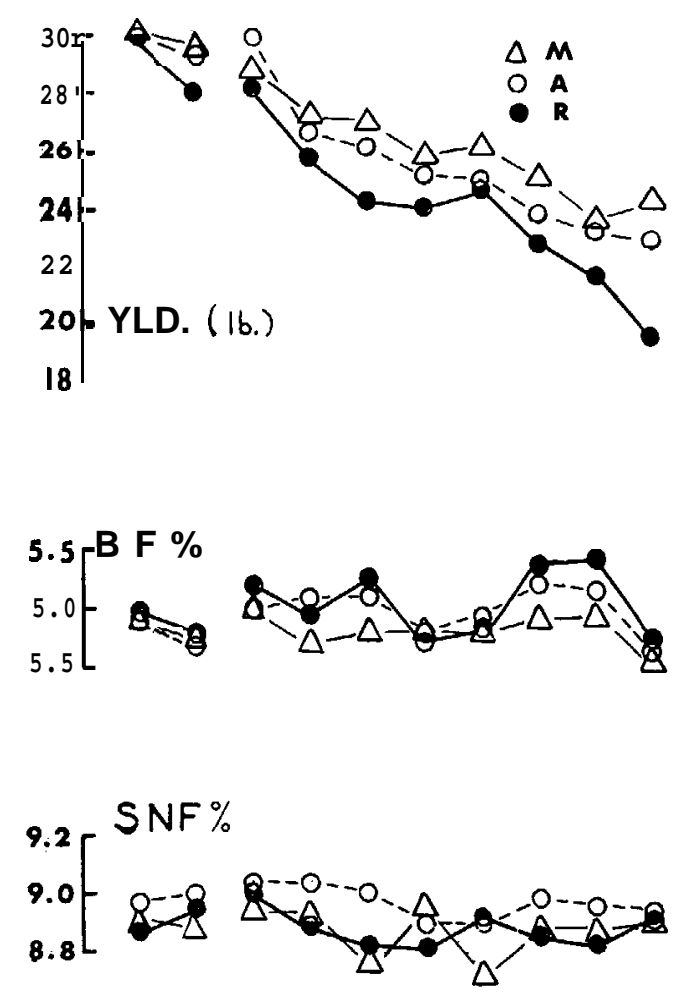

$$
\text { SEPT } 1 \text { OCT : NOV }
$$

FIG. 1: Average daily milk yield and composition from groups of eight animals grazmg Manawa $(M)$, Ariki $(\mathrm{A})$ and Ruanui $(R)$ ryegrasses during the spring period. The first two samples were obtained from all cows while grazing a mixed pasture sward.

between the Manawa and Ruanui groups being $5.0 \mathrm{lb}$ milk per cow per day. Butterfat percentage was slightly higher in the milk of the cows grazing Ruanul ryegrass and, although butterfat yields did not differ significantly, they were similar in order to the milk yields.

A number of other general observations were made relating to pasture conditions, stock health, and production. Production from the cows grazing pure ryegrass swards was much lower than that of the remainder of the herd grazing mixed pasture. Grass staggers (hypomag- 
nesaemia) occurred on all three pure swards but not on mixed pasture. The Manawa pastures were destroyed during each summer by infestations of Argentine stem weevil but A riki and Ruanui ryegrasses were not noticeably affected.

The major deficiency inherent in the use of animal output, as a sole criterion for evaluating pastures, is that, it seldom provides reasons for the differences observed between the pastures being compared. It is normally necessary, therefore, in investigations of this nature, to measure as many different variables contributing to nutritive value as is possible. With this in mind, an indoor feeding experiment was undertaken in conjunction with the grazing experiment described. Six lactating animals with rumen fistulae were allocated to three groups, and each group was fed one of the three ryegrasses (Wilson,

1966). In this experiment, the apparent digestibility of the Manawa ryegrass was two to three percentage units higher than that of the other two varieties. No significant differences were found between the total concentration of volatile fatty acids or the molar proportion of acetic, propionic and butyric acids in the rumen liquor taken from the cows fed the different ryegrasses. It was concluded, therefore, that while minor differences in the digestibility of the ryegrasses may have contributed to the observed differences in milk production in the grazing experiment, voluntary intake differences between groups was probably the major factor involved.

\section{Autumn EXPERIMENTS}

During the autumn growth period, Ariki ryegrass was compared with Ruanui ryegrass. Grazing commenced when the pastures were leafy and 4 to $8 \mathrm{in}$. high. Ariki pastures grew much more rapidly than Ruanui and appeared greener and of higher quality, partly because the latter became infested with stem rust. The results of two experiments, each lasting three weeks, are presented in Fig. 2.

In both experiments, the Ruanui group produced a higher yield of milk and butterfat than the A riki group. The butterfat content of the milk from the A riki group was increased considerably in both experiments and solids-not-fat content reduced in the second experiment.

The grazing behaviour of the cows grazing A riki ryegrass was abnormal, in that they apparently found this grass unpaiatable. The changes in milk yield and composition are also in accord with a lower voluntary intake of this 

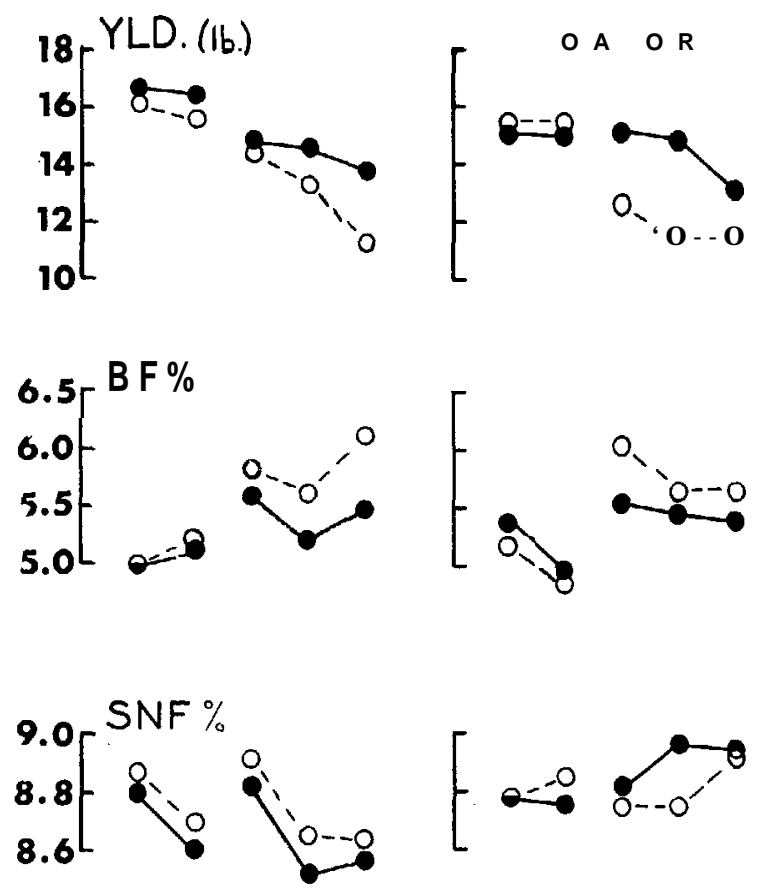

II/2 I8 $25, .4 / 3 \quad 11$

$27 / 3 \quad 1 / 4 \quad 8 \quad 15 \quad 22$

FIG. 2: Average daily milk yiedd and composition from eight pairs of twins grazing Ariki (A) and Ruanui $(R)$ ryegrasses during two autumn periods. (First two samples, mixed pasture feeding.)

ryegrass. In view of the possible importance of this observation, two further autumn experiments were undertaken in which Ruanui and Ariki ryegrasses were each grown together with white clover. The results, presented in Fig. 3, indicate that milk yield and fat percentage were similar for the two ryegrasses when grown with clover. However, in both experiments the solids-not-fat content of the milk produced by the Ruanui group was very low.

A large reduction in level of nutrition is the only known factor which can lead to a drop in solids-not-fat percentage of the order obtained in these experiments, but this was clearly not responsible in the present experiments. That a difference in ryegrass variety in association with the same clover can give rise to such changes without affecting milk or fat yield is not only unique, but may also be economically important to the dairy industry in New Zealand. 


\section{ANNUAL VARIETIES}

During the 1966-7 dairying season, 'Grasslands 4707' tetraploid Western Wolths ryegrass, which was described by Barclay and Vartha (1966), was compared in terms of its effect on milk yield and composition with 'Grasslands Paroa' ryegrass and Ruanui ryegrass. The inclusion of Ruanui ryegrass in this comparison was expected to give maximum chemical differences, at present obtainable, between existing ryegrass varieties at similar stages of growth.

Two grazing experiments were undertaken, one in June with groups of Friesian cattle, and a second in October using predominantly Jersey twin cattle.

\section{WINTER EXPERIMENT}

In the winter experiment lasting two weeks (Fig. 4), cows on Western Wolths and Paroa ryegrass produced a
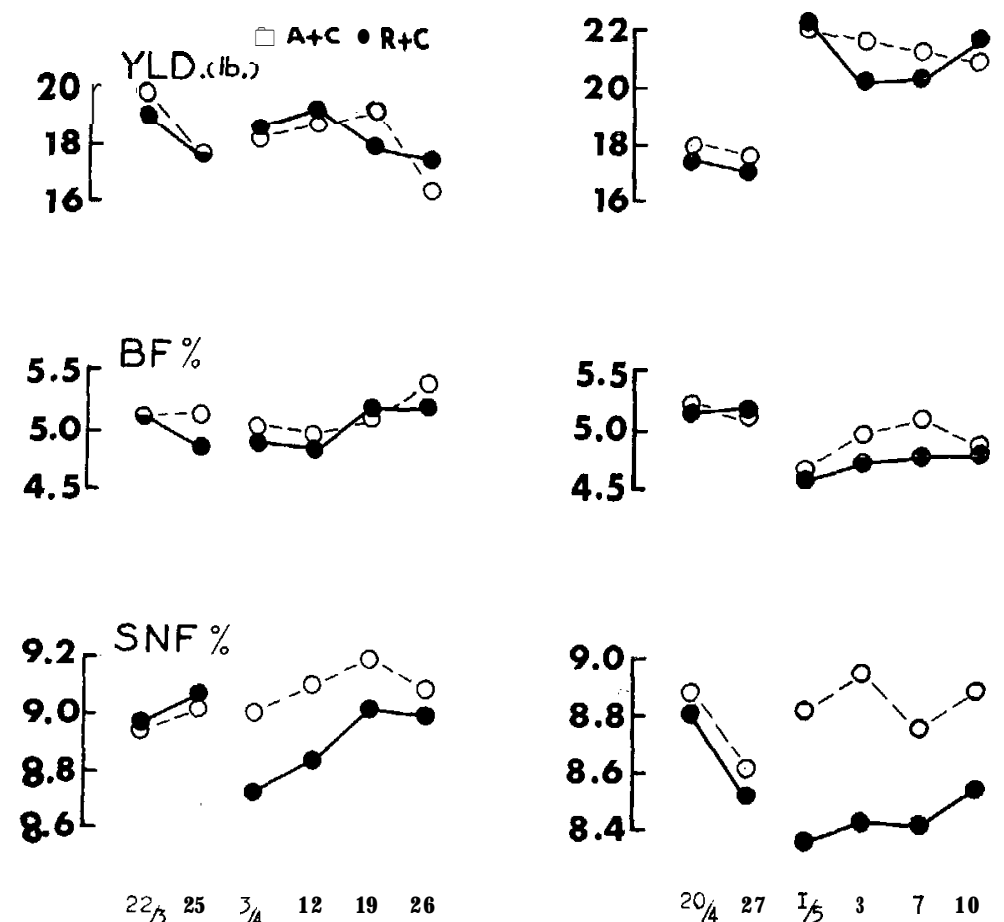

Fig. 3: Average daily milk yield und composition from twin cows grazing Ariki/clover $(A+C)$ and Ruanui/clover $(R+C)$ swards during the autumn periods. (First two samples, mixed pasture feeding.) 


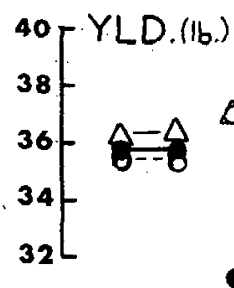

${ }_{3.5}^{4.5}\left[\begin{array}{l}B F \% \\ -A=-0\end{array}\right.$
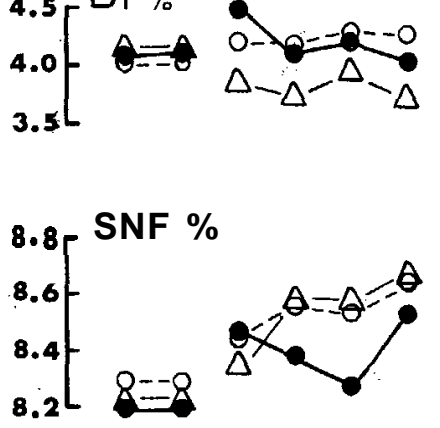

$I 3 / 6 \quad 15 \quad 20 \quad 22 \quad 26 \quad 29$
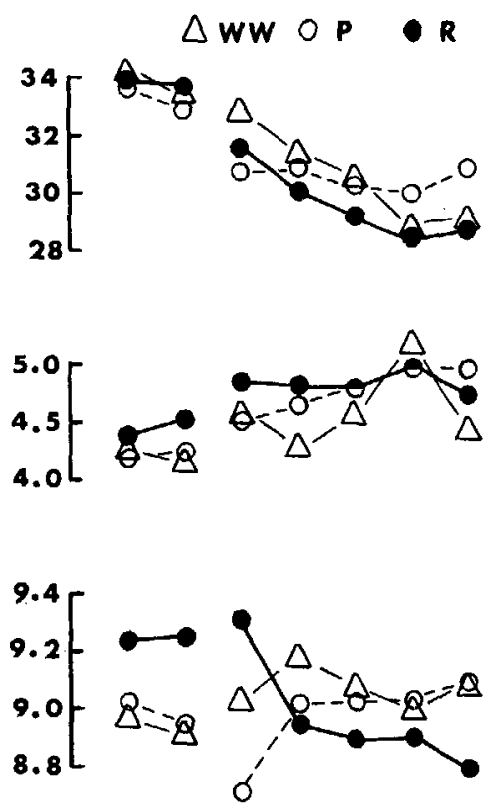

25\% 310 IO 12 I7 $19 \quad 23$

FIG. 4: (Left) Average daily milk yield and composition from groups of Friesian cattle grazing Western Wolths (WW), Paroa (P), and Ruanui (R) ryegrasses during June.

(Right) A similar comparison using twelve pairs of twins during October (The firsf two samples in each experiment, mixed pasture feeding.)

higher yield of milk than those grazing Ruanui ryegrass, but the milk from the Western Wolths group contained a significantly lower percentage of butterfat. Butterfat yield was hence greatest from the Paroa, intermediate from Western Wolths, and lowest from Ruanui. The solids-notfat content of the milk produced by the Ruanui group was lower than the values for the other two groups which, together with the milk yield reduction, suggested that the Ruanui cows had a lower net energy intake. At least part of this possible difference in net energy intake could be explained by the fact that the in vitro digestibility coefficient (Tilley and Terry, -1963) for the Ruanui pasture was about $2 \%$ lower than the corresponding figure for Western Wolths ryegrass. 
MILK PRODUCTION FROM RYEGRASS

TABLE 1: MOLAR PROPORTIONS OF VOLATILE FATTY ACIDS IN THE RUMEN LIQUOR OF COWS GRAZING WESTERN WOLTHS. PAROA AND RUANUI RYEGRASSES

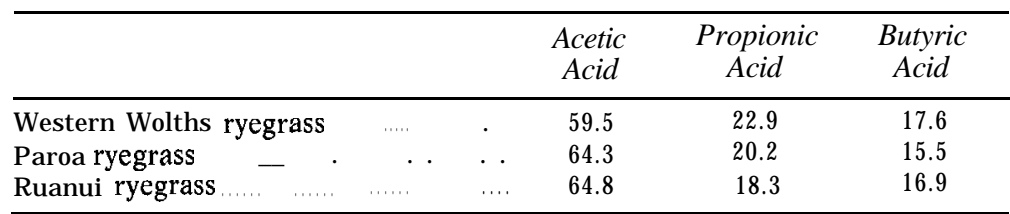

The differences in butterfat percentage between the Paroa and Western Wolths groups were associated with a difference in the proportion of volatile fatty acids present in the rumen liquor, as shown by samples taken from two rumenfistulated cows on each of the treatments (Table 1).

The relatively high level of propionic acid and the lower level of acetic acid in the rumen liquor of the cows grazing Western Wolths were probably responsible for the de pressed butterfat percentage in the milk. This conclusion is suggested by experiments in which the feeding of starchy concentrates has given reductions in milk fat together with a low acetic to propionic acid ratio in the rumen liquor (Balch et al., 1952). In addition, intra-ruminal infusions of propionic acid have given reductions in the butterfat content of milk (Wilson et al., 1967).

SPRING EXPERIMENT

In the spring comparison, which lasted three weeks (Fig. 4), milk yield and butterfat percentages were very similar in the three groups. However, the solids-not-fat percentage of the milk produced by the Ruanui group was considerably lower than that of the others. The crude fibre contents of the ryegrasses were higher in the spring than in the winter, and this may explain both the absence of an effect by Western Wolths on fat percentage and the smaller differences obtained between the molar proportions of individual volatile fatty acids produced by the cows grazing the three ryegrasses.

The ryegrasses differed in organic matter digestibility, with Western Wolths the highest at $71.5 \%$, followed by Paroa with $70.5 \%$ and Ruanui with $69.0 \%$. Because volatile fatty acids proportions did not differ greatly, and since the plane of nutrition was fairly similar in the three groups as judged by similarity in milk yields, it is not possible at present to explain the low solids-not-fat percentage in the milk from the Ruanui group. 


\section{CONCLUSIONS}

Considerable differences in the nutritive value of ryegrass strains, as measured by their effects on milk production and composition, do exist, so that at this stage some general conclusions maybe suggested.

Increased milk yield appears to be associated with a lower content of crude fibre, and probably also with ryegrass strains with a high organic matter digestibility.

Butterfat yield is closely related to milk yield in the case of most of the ryegrasses, but it is clear that butterfat percentage and yield can be depressed at high milk yields If the chemical nature of the plant is such that it leads to a low proportion of acetic acid to propionic acid in the rumen liquor. The chemical characteristics which are most likely to be important in this regard are. very low. levels of crude fibre, in conjunction with high levels of soluble sugars. It is suggested, therefore, that an optimum percentage of crude fibre probably exists for maximum butterfat production.

Solids-not-fat yield, too, is generally closely associated with milk yield, but large reductions in solids-not-fat percentage, and hence yield, can unfortunately be encountered when grazing the widely used Ruanui ryegrass. Further work is being carried out to investigate this Interesting and important phenomenon.

\section{REFERENCES}

Balch, C. C.; Balch, D. A.; Bartlett, S.; Cox, C. P.; Rowland, S. J. 1952: J. Dairy Res., 19: 39.

Barclay, P. C.; Vartha, E. W. 1966: Proc. 28th Conf. N.Z. Grad Ass., 184. Tilley, J. M. A.; Terry, R. A. 1963: J. Brit. Grad. Soc., 18: 104.

Wilson, G. F. 1966: N.Z. J. agric. Res., 9: 1053.

Wilson, G. F.; Davey, A. W. F.; Dolby, R. M. 1967: N.Z. J.agric. Res., 10 215 .

\section{DISCUSSION}

In the experiments, was there a measure of intake of the various grasses? What was the proportion of clovers in the various pastures?

Intakes were not measured. The design of the experiment was such that both intake and quality of pastures were measured indirectly by measuring animal output.

The proportion of clovers in the two pastures was similar and contributed to the extent of about $50 \%$ of the dry matter yield. 
What is the reason for the lack of paintability of Ariki ryegrass?

I suspect that the unpalatability observed in each autumn experiment was related to the high nitrogen levels in Ariki ryegrass.

COMMent (DR L. Corkili): Because of the artificial conditions in using one species topdressed with nitrogen, it is likely that the unpalatability of Ariki ryegrass is related to the high levels of protein and possibly nonprotein nitrogen in the herbage. I consider that the experiments are of more value to plant breeders than to dairy farmers.

Is the proportion of volatile fatty acids due to the fibre content of the grass?

The volatile fatty acid proportions are likely to be influenced by all components of the pasture but the ratio of insoluble to soluble carbohydrates is generally the most important factor.

Were minerals fed to stock grazing single species?

A mineral lick was available during the long-term experiments but not during the short-term ones.

In what way did the results reflect the origins of the ryegrass?

The chemical composition of the pastures, particularly crude fibre and soluble sugar levels, and the proportions of volatile fatty acids produced by cows reflect the genetic origins of the ryegrasses. 